\title{
Vale Neil McKern - Australian insulin receptor scientist
}

\author{
Colin Wesley Ward ${ }^{1}$ * and Michael Colin Lawrence ${ }^{1,2}$ * \\ Walter and Eliza Hall Institute of Medical Research, Parkville, VIC, Australia \\ ${ }^{2}$ Department of Medical Biology, University of Melbourne, Parkville, VIC, Australia \\ *Correspondence: cward@wehi.edu.au; lawrence@wehi.edu.au \\ Edited and reviewed by: \\ Briony Forbes, The University of Adelaide, Australia
}

Keywords: Neil McKern, insulin receptor, type 1 insulin-like growth factor receptor, epidermal growth factor receptor, ErbB2

Neil Moreton McKern, the first author on the landmark paper describing the crystal structure of the human insulin receptor ectodomain (1), passed away on the 20 March 2014 after a year-long battle with multiple myeloma.

Neil McKern was born on 17 December 1946 at Richmond, New South Wales. His career in science began at the age of 18 as a technical assistant to Dr. Fred Stewart in the CSIRO Division of Protein Chemistry in Parkville, VIC, Australia, where he worked on the chemical synthesis of the peptide hormone oxytocin. Neil then studied part time, obtaining a B.Sc. degree in 1971 and a Ph.D. degree in 1981, both from the University of Melbourne. His thesis title was "Serum somatomedin and the regulation of growth-studies with rodent models."

Over the subsequent 10 years at CSIRO, Neil contributed to several aspects of protein science, including the purification of wool proteins for structure determination, the sequencing of the pilin protein of Dichelobacter nodosus (which causes footrot in sheep), the study of the proteins of infectious bursal disease virus (a major poultry pathogen) coupled with development of a recombinant vaccine, and the study of variation in the coat protein sequence across the Potyviridae (the largest family of plant viruses). These projects reflected the agricultural priorities of CSIRO's science at the time.

These endeavors laid the foundation for Neil's involvement starting in 1992 with what was to become a "grand challenge" at CSIRO, namely, Colin Ward's program to understand the structural biology of the insulin receptor, the Type 1 insulin-like growth factor, and the epidermal growth factor receptor. Spurred on by the successful determination of the structure of the human growth hormone bound to its receptor by Tony Kosiakoff and colleagues at Genentech, the allure of a structure of insulin bound to its receptor was irresistible. However, the complexity of these receptor ectodomains proved to be substantial - high levels of glycosylation, high numbers of disulfide bonds, and the existence of multiple liganded states. Neil masterminded the practicalities of purifying bulk quantities of the ectodomains and truncated ectodomain fragments of these receptors from large ( 100 l plus) scale mammalian cell culture supernatants. His demands were high - to achieve tens of milligram quantities of receptor protein displaying no more than one band on an isoelectric focusing gel. He set up the first forays of the lab into robotic protein crystallization and the combination of this technology with isoelectrically pure protein finally delivered the first - and still only-structures of the Type 1 IGF-1 receptor L1-CR-L2 fragment (2), the insulin receptor L1-CR-L2 fragment (3), and the

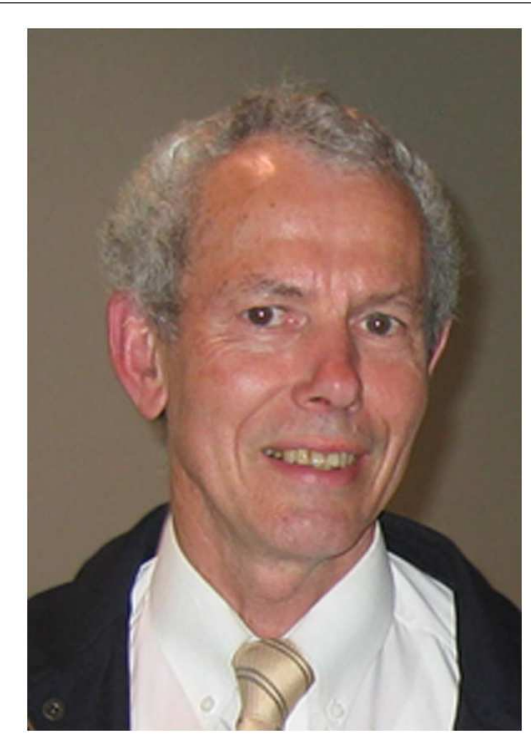

FIGURE 1 | Neil McKern in 2006 intact insulin receptor ectodomain (1). Such care and ingenuity absorbed Neil until 2007, at which point CSIRO terminated the project upon Colin's retirement. His endeavors also led to structures of the truncated ectodomains of the epidermal growth factor receptor in complex with TGF $\alpha$ (4) and of its co-family member ErbB2 (5). Neil retired from CSIRO in 2010, but not before playing a key role in ensuring that the structural studies of the insulin receptor continued at the neighboring Walter and Eliza Hall Institute of Medical Research in Melbourne.

Always striking to all Neil's colleagues was his cheerful optimism, which was coupled with healthy cynicism about the way in which his employing organization functioned. Part of this optimism derived no doubt from his passion for running, which seemed to not only energize his body but also to provide a wealth of ideas about how to prepare the next sample for crystallization. Giving up on the "grand challenge" would have to Neil been akin to pulling out of a marathon half way along the course.

Neil was dedicated to his family, which together faced the challenge of re-building their beloved family retreat in Marysville after it burnt to the ground in the devastating Black Saturday bushfires of 2009.

For us, and for the many others who worked with him, his enthusiasm for science, and his collegial support is greatly missed.

\section{ACKNOWLEDGMENTS}

Financial support from the Hazel and Pip Appel Fund (to Michael Colin Lawrence) and the NHMRC Independent Research Institutes Infrastructure Support Scheme Grant 361646 and Victorian State Government Operational Infrastructure Support Grant (to the Walter and Eliza Hall Institute of Medical Research) is acknowledged. 


\section{REFERENCES}

1. McKern NM, Lawrence MC, Streltsov VA, Lou MZ, Adams TE, Lovrecz GO, et al. Structure of the insulin receptor ectodomain reveals a folded-over conformation. Nature (2006) 443:218-21. doi:10. 1038/nature05106

2. Garrett TP, McKern NM, Lou M, Frenkel MJ, Bentley JD, Lovrecz GO, et al. Crystal structure of the first three domains of the type-1 insulin-like growth factor receptor. Nature (1998) 394:395-9. doi:10.1038/ 28668

3. Lou M, Garrett TP, McKern NM, Hoyne PA, Epa VC, Bentley JD, et al. The first three domains of the insulin receptor differ structurally from the insulinlike growth factor 1 receptor in the regions governing ligand specificity. Proc Natl Acad Sci US A (2006) 103:12429-34. doi:10.1073/pnas.0605395103
4. Garrett TP, McKern NM, Lou M, Elleman TC, Adams TE, Lovrecz GO, et al. Crystal structure of a truncated epidermal growth factor receptor extracellular domain bound to transforming growth factor alpha. Cell (2002) 110:763-73. doi:10.1016/ S0092-8674(02)00940-6

5. Garrett TP, McKern NM, Lou M, Elleman TC, Adams TE, Lovrecz GO, et al. The crystal structure of a truncated ErbB2 ectodomain reveals an active conformation, poised to interact with other ErbB receptors. Mol Cell (2003) 11:495-505. doi:10.1016/ S1097-2765(03)00048-0

Conflict of Interest Statement: The authors declare that the research was conducted in the absence of any commercial or financial relationships that could be construed as a potential conflict of interest.
Received: 19June 2014; accepted: 19 June 2014; published online: 03 July 2014.

Citation: Ward CW and Lawrence MC (2014) Vale Neil McKern - Australian insulin receptor scientist. Front. Endocrinol. 5:105. doi: 10.3389/fendo.2014.00105

This article was submitted to Molecular and Structural Endocrinology, a section of the journal Frontiers in Endocrinology.

Copyright (c) 2014 Ward and Lawrence. This is an openaccess article distributed under the terms of the Creative Commons Attribution License (CC BY). The use, distribution or reproduction in other forums is permitted, provided the original author(s) or licensor are credited and that the original publication in this journal is cited, in accordance with accepted academic practice. No use, distribution or reproduction is permitted which does not comply with these terms. 